\title{
Galin Tihanov, The Birth and Death of Literary Theory: Regimes of Relevance in Russia and Beyond. Stanford, CA: Stanford University Press, 2019. 258 pages. $\$ 60$. Hardcover ISBN: $9,780,804,785,228$
}

\section{Lina Steiner ${ }^{1} \mathbb{D}$}

Accepted: 8 May 2021 / Published online: 16 June 2021

(c) The Author(s) 2021

\begin{abstract}
This review discusses an important recent book by Galin Tihanov, the George Steiner Professor of Comparative Literature, Queen Mary University of London.
\end{abstract}

The Birth and Death of Literary Theory explores the history of a crucial twentiethcentury episteme: literary theory. The subtitle of this book, Regimes of Relevance in Russia and Beyond, harks back to Foucault. Coined by analogy with the Foucaultian "regime of truth," the expression "regime of relevance" refers to the mechanisms and conditions that shape the predominant understanding and use of literature at a particular time and place. The particular "regime of relevance" that Galin Tihanov examines in this carefully researched study values literature as a unique and autonomous discourse that differs from other discourses, such as journalism, philosophy, everyday speech, etc. Tihanov maintains that "literary theory" in its current sense emerged in the wake of World War I, which caused a massive emigration and displacement of intellectuals throughout Central and Eastern Europe. Exile was a key aspect in the formation of literary theory insofar as it encouraged scholars to think about literature beyond the boundaries of their native languages and literary traditions. While Romanticism channeled the notion of the autonomous value of literature through the figure of the artistic genius, twentieth-century theory linked the worth of literature directly to language (3). It was language, understood as a product and vehicle of human creativity, that underlay the notion of literariness put forth by Russian Formalism, which Tihanov sees as the first modern critical movement to develop a rigorous approach to the study of literary language. But although the Formalists (Viktor Shklovsky, Boris Eikhenbaum, Roman Jakobson, and others)

Lina Steiner

lsteiner@uni-bonn.de

1 International Centre for Philosophy, University of Bonn, Poppelsdorfer Allee 28, 53115 Bonn, Germany 
were the first to announce the birth of a new method of literary study, literary theory was not an entirely Russian invention. As Tihanov points out in the "Introduction," scholars from Czechoslovakia, Hungary, and other East and Central European countries also partook of this episteme (11). Therefore his decision to limit the scope of the book to Russian literary theory was clearly dictated by Tihanov's rigorous scholarly methodology based on archival research, rather than by a tacit bias.

In addition to historical cataclysms which uprooted many intellectuals and forced them to start thinking about literature theoretically, i.e., in ways that could be comprehensible to inheritors of different national traditions, the rise of literary theory was conditioned by the disintegration of monolithic philosophical systems (Hegelianism, neo-Kantianism, etc.). Literary theory endeavored to replace philosophical aesthetics, which bestowed transcendent value on the work of art (16-18). As Tihanov demonstrates in his nuanced analyses of Russian Formalism and Bakhtin's philosophy of culture (discussed in chapters 1 and 3, respectively), the rejection of aesthetics by these scholars was symptomatic of a larger crisis- the crisis of traditional humanism that saw human beings as the center of the universe. Among the heroes of Tihanov's narrative, only Gustav Shpet (whose career is the focus of chapter 2) did not disavow aesthetics and its concomitant principles of subjectivity and autonomy. All other movements discussed in this book looked to Saussurean linguistics, anthropology, and natural science to suggest new approaches to literary study. This quest for scientific rigor and objectivity, combined with a distrust of individual value judgment, belongs to the mental framework of late modernity-the Zeitgeist that still dominates our consciousness. Therefore, the ideas discussed in this book are not merely of historical value. Institutionally, literary theory may have been defunct since the end of the twentieth century, but its legacy still remains a hotly contested issue. While some theoretical concepts have been absorbed by the neighboring disciplines, such as philosophy, semiotics, and cultural studies, a number of important ideas still await a more profound investigation and comprehension. These are precisely the tasks that Tihanov's book fulfills.

That the author's goals are not merely "antiquarian" becomes clear at the beginning of chapter 1. The reader is invited to reexamine Russian Formalism from today's perspective and reflect on its legacy not as a literary theory per se, but as part and parcel of a broader intellectual and cultural transformation that is still underway. "By giving Formalism a pride of place as the originator of modern literary theory, are we not at the same time concealing its immersion in a much wider-and more consequential - agenda that sought to redefine the status of human agency beyond the crumbling foundations of humanism?" asks Tihanov (27). To answer this question, he first compares Russian Formalism with psychoanalysis. Freud's project was designed to show that our psychic life is guided by rules that are beyond our control, and yet are knowable by us. Likewise, Formalism insisted that the writer's work is guided by the objective laws of plot, device, rhyme, and rhythm (32). But the most illuminating comparison is between Formalism and Marxism. Usually regarded as foes, in Tihanov's study Formalism and Marxism emerge as competitors in the field of rational inquiry into objective laws that govern human agency.

At the same time, Tihanov suggests that the similarities between Formalism and Marxism should not be exaggerated. The relationship between the two movements 
was asymmetrical insofar as already in the mid-1920s Marxism was grappling for intellectual hegemony, whereas Formalist critics were undergoing a process of genuine self-questioning and maturation which brought them closer to Marxist sociology. In Tihanov's view, the famous 1927 debate between Marxist and Formalist critics in Leningrad became possible thanks to the internal evolution of the Formalists, especially Boris Eikhenbaum and Boris Tomashevskii, and their recognition that the study of extraliterary series (riady) is indispensable and essential (37). The Marxists, on the other hand, proved unwilling to enter into a genuine dialogue with the Formalists. According to Tihanov, the Marxists' reluctance to engage in a real conversation with their competitors and reflect critically on their own methodological assumptions revealed the resilience of an older "regime of relevance"-one that bestowed significance upon literature when it was useful to other social and political agendas (38).

After revisiting the 1927 debate, the author turns to the figure of Viktor Shkolvsky, whose conception of "estrangement" (ostranenie) is often regarded as a synecdoche of the entire Formalist movement. The bulk of the chapter is dedicated to a careful historical analysis of Shklovsky's early works composed during World War I (in which the future critic took part as a soldier). This biographical fact links Shklovsky to a number of European intellectuals of the same generation whose ideas were rooted in their wartime experiences. If we look at Shklovsky's early writings as part of a larger European constellation, his theory of "estrangement" appears somewhat paradoxical. Tihanov demonstrates that Shklovsky, just like his contemporaries Georg Simmel and Ernst Jünger (and a number of other European intellectuals), was concerned with the increasing automatization of life and the ensuing dampening of sense perception. While Simmel and Jünger saw war as the catalyst of sensuous and spiritual revitalization in the decadent old Europe, Shklovsky assigned this role to Futurist poetry. And yet, one cannot help but notice the disturbing affinities between Shklovsky's discussion of "estrangement" in "Art as Device" and his German contemporaries' instrumentalization of war as the means of cultural rejuvenation. Chapter 1 concludes with a fascinating discussion of the afterlife of "estrangement" in the work of Berthold Brecht and Herbert Marcuse. In the case of Brecht, there is no proof of direct influence. Nevertheless, Shklovsky's "estrangement" and Brecht's Verfremdungseffekt are strikingly similar. Marcuse, on the other hand, did read "Art as Device" in an anthology of Russian Formalism published by Tzvetan Todorov in 1965 and found it relevant to his own analysis of the role of art in the potential transformation of bourgeois society (55).

Whereas Formalism is one of the best-known intellectual movements that emerged in Russia, the figure of Gustav Shpet still remains largely unknown to Western literary scholars (as opposed to philosophers). The second chapter of The Birth and Death of Literary Theory offers a succinct intellectual biography of this remarkable thinker, which helps us get a new angle on the Russian and Soviet intellectual scene in the 1920s and 1930s. Drawing on previously unheeded published and unpublished sources, Tihanov reconstructs Shpet's participation in the Russian and Soviet theater and literary scene. A friend of Viacheslav Ivanov (who acted as a kind of mentor to Shpet), Andrei Bely, and a number of other Silver Age poets, artists, and intellectuals, Shpet was extremely well informed about contemporary 
literature and theater. He was also an accomplished literary translator, and after his dismissal from the Russian State Academy of Artistic Sciences (Gosudarstvennaia Akademiia Khudozhestvennykh Nauk, GAKhN), he made his living translating literary classics from English, German, and other languages. His ultimate achievement in this area was his translation of Hegel's Phenomenology of Spirit, completed during his exile in Tomsk. In the 1920s Shpet was also a member of the Moscow Linguistic Circle. Tihanov shows that Shpet's Aesthetic Fragments had a major impact on the work of the circle. Thus it was Shpet who offered the first Russian definition of poetics as grammar-a point later taken up and developed by Jakobson in his famous essay "The Poetry of Grammar and the Grammar of Poetry" (87).

Another crucial idea in Aesthetic Fragments is the definition of the structure of the word and its differentiation from "system," a term Shpet applied to discourse. As Tihanov points out, Tynianov's and Jakobson's 1928 theses on research in literature and language developed the idea of a correlation between literature and other cultural "series" (riady), which they called, echoing Shpet, a "system of systems." Notwithstanding these similarities in their thinking, Jakobson criticized Shpet for being insufficiently radical, whereas Shklovsky and Eikhenbaum regarded him as downright conservative and thus one of their foes.

According to Tihanov, the reason for this animus was Shpet's enduring commitment to aesthetics. As a phenomenologist, Shpet's chief concern was to understand under what conditions an utterance can become the vehicle of aesthetic experience (89). Tihanov's analysis of Shpet's unpublished Literary Studies shows that his views on literary genre were also out of sync with those of his more radical contemporaries, such as Bakhtin. In analyzing the novel, Shpet, like Bakhtin, takes his cue from Georg Lukács' Theory of the Novel, which juxtaposes epic and novel. But while Bakhtin valorizes the novel, which he transforms into écriture that transcends the restrictions of mere genre, Shpet regards the novel as no more than a degraded form of the epic, marked by a series of lacks, of composition, plan, and "inner form" (91). The comparison between Shpet's and Bakhtin's interpretations of the novel at the end of chapter 2 completes Shpet's intellectual profile as a rather anachronistic thinker, a Humboldtian philosopher of language and aesthetician amidst post-Saussurean linguists and Marxist literary theorists. This chapter, however, is very important insofar as it reconstructs the intellectual breadth of the early Soviet period, offering a perfect lead-up to the discussion of Bakhtin's conceptions of polyphony and heteroglossia in the next chapter.

Chapter 3 opens with a brief discussion of Bakhtin's intellectual trajectory, which Tihanov summarizes as a movement from aesthetics and ethics to philosophy of culture. The main thrust of this chapter is to show how Bakhtin forged a theoretical platform informed by what Tihanov calls "humanism without subjectivity" (107). He argues that Bakhtin's mature and late writings revolved "not around the individual but around the generic abilities of the human species to resist and endure in the face of natural cataclysms or the ideological monopoly on truth" (107-108). Bakhtin's work which best illustrates this decentered humanism is Rabelais and His World. Tihanov interprets this work against the background of the German debates on modernity that unfolded during the Nazi period. He points out that such terms as "heteroglossia" and "horizon" were first used by the German sociologist Hans 
Freyer, whose work Bakhtin must have known. In the absence of a homegrown hermeneutic tradition (Shpet's Hermeneutics and Its Problems was still unpublished and unavailable to Bakhtin), it was Freyer's and Hans-Georg Gadamer's discussions of community, tradition, and the classic that informed Bakhtin's quest for a modern classic. He ultimately attained this goal by "reconfiguring the novelistic in a way that opens it up to the influx of epic elements" (117). In Bakhtin's interpretation, Rabelais's Gargantua and Pantagruel emerges as a synthesis of the novel and the epic.

Chapter 4 introduces yet another understudied intellectual movement: semantic paleontology. Although the name of its leader, the linguist Nikolai Marr, is quite well known, the role of semantic paleontology in the 1930s debates on the methodology of literary studies has never been examined systematically (134). Semantic paleontology was a method that enabled scholars to penetrate the depths of glottogenesis. Marr believed that languages evolved from multitude and diversity toward unity. He denied the existence of an Indo-European proto-language and argued that similarities between languages could be explained by the similarities of their socioeconomic development. Marr himself did not apply his method to literary studies. This was done by other scholars, most notably by Ol'ga Freidenberg and Izrail' Frank-Kamenetskii. The bulk of chapter 4 discusses the ideas of these scholars against the background of Formalism (which the paleontologists saw as their principal opponent), Marxism, and vulgar sociology. As Tihanov points out, along with Formalism, Marxism, and psychoanalysis, paleontology partook of a larger paradigm of a literary history "without names." Yet Freidenberg and Frank-Kamenetskii were the most radical exponents of this trend. The genetic method they practiced questioned the very core of literature by inquiring into what was there before literature" (139). They believed that the growth of culture can be traced with reference to myth, folklore, and, finally, literature. Importantly, paleontology annulled the "divorce" between literary studies and linguistics, which had been characteristic of Marxist sociologically oriented criticism.

The fifth and last chapter examines critical and theoretical debates among Russian émigré intellectuals between the two world wars. Unlike émigré literature, émigré criticism has received very little scholarly attention. Tihanov's book fills this lacuna by offering a fascinating account of three important debates that unfolded among Russian intellectuals in Prague, Berlin, and Paris: the exchanges on the role of criticism; the debate on "young literature," which was in fact a debate on the future of émigré literature; and the ongoing debate about the literary canon. Carefully reconstructed by Tihanov, these discussions shed new light not only on the ideological polemics among Russian émigrés and their difficult everyday life (literaturnyi byt), but also on the complex relationship between the émigré culture and the official Soviet culture.

The Birth and Death of Literary Theory concludes with an epilogue that reflects on the fate of literary theory in contemporary academia. In our epoch of cultural and intellectual mobility, it is the growing subfield of "world literature" that appears to be the main heir of theory. Tihanov shows that there are indeed some affinities between these fields. For example, the Anglo-American theorists of world literature have sought to legitimize the study of literature in 
translation (in this connection, Tihanov mentions David Damrosch, but one could also mention Wai Chee Dimock and her idea of "planetary" literature). This approach, however, had already been suggested by Russian Formalists. Thus Tihanov reminds us that both Shklovsky and Eikhenbaum maintained that literariness materializes on the level of composition, rather than on the microlevel of particular language (182). Although Shklovsky was wary of Gorky's project of translating and publishing the "classics of world literature" (which imposed a non-negotiable canon on Soviet readers), he often worked with translated texts. Eikhenbaum also highlighted that literariness could be appreciated in translated works (182).

Tihanov makes another interesting point. He suggests that Shklovsky's playful attempt to apply the compositional technique of "estrangement" to his own fictionalized memoirs, Sentimental Journey and Zoo, or Letters Not about Love, can be seen as an attempt to practice theory without a theoretical meta-language. These experiments and Shklovsky's intervention in the debate on world literature sparked by Gorky's project extended the life of his theory across time and space (184). In the end, it appears that theory did not die, but transformed or migrated into other discourses. Thus, the epilogue to Tihanov's book, like the epilogues to some of the best Russian novels, is not so much an ending as a beginning of a new story. This realization brings to mind the fact that the "birth and death" metaphor is used by statisticians and evolutionary biologists to describe a stochastic process, where the disappearance of something old is always compensated by the emergence of something new. Given that literary theory was but one of many attempts at serious, methodical reflection on literature that our civilization has known, there is every reason to believe that its decline will bring in its train new schools of thought. Of course, one can hardly disagree with Tihanov's claim that the "regime of relevance" which favored literary theory has already expired. In this day and age, literature is becoming part of the entertainment industry and is losing its claim to uniqueness and autonomy, and as entertainment, it is likely to lose the competition for popularity with mechanically produced art. However, the increasing dominance of cinema and visual art is not only a cause for concern, but also a stimulating challenge which has already given rise to fruitful collaborations between literature and other media, and between literary and media studies. The past few decades also witnessed an increasingly lively and promising dialogue between moral philosophers and literary critics, as well as between analytic philosophers and literary theorists. All these tendencies testify to the importance and timeliness of Galin Tihanov's new book. This work will be greatly appreciated by scholars from many different fields across the humanities and social sciences.

Funding Open Access funding enabled and organized by Projekt DEAL. This review was not funded by any funding agency. 


\section{Declaration}

Conflict of interest There is no conflict of interest between the reviewer and the author of this book.

Ethical standards There is nothing in this text that might raise any ethical issues.

Open Access This article is licensed under a Creative Commons Attribution 4.0 International License, which permits use, sharing, adaptation, distribution and reproduction in any medium or format, as long as you give appropriate credit to the original author(s) and the source, provide a link to the Creative Commons licence, and indicate if changes were made. The images or other third party material in this article are included in the article's Creative Commons licence, unless indicated otherwise in a credit line to the material. If material is not included in the article's Creative Commons licence and your intended use is not permitted by statutory regulation or exceeds the permitted use, you will need to obtain permission directly from the copyright holder. To view a copy of this licence, visit http://creativecommons.org/licen ses/by/4.0/.

Publisher's Note Springer Nature remains neutral with regard to jurisdictional claims in published maps and institutional affiliations. 